Published in final edited form as:

Microvasc Res. 2008 January ; 75(1): 1-8.

\title{
MOLECULAR MECHANISMS OF PREECLAMPSIA
}

\author{
Walter P. Mutter ${ }^{1}$ and S. Ananth Karumanchi, M.D. ${ }^{1,2}$ \\ 1 Department of Medicine, Beth Israel Deaconess Medical Center and Harvard Medical School, Boston, MA \\ 2 Department of Obstetrics and Gynecology, Beth Israel Deaconess Medical Center and Harvard Medical \\ School, Boston, MA
}

\begin{abstract}
Preeclampsia is a major cause of maternal, fetal, and neonatal mortality worldwide. The mechanisms that initiate preeclampsia in humans have been elusive, but some parts of the puzzle have begun to come together. A key discovery in the field was the realization that its major phenotypes, such as hypertension and proteinuria, are due to excess circulating soluble fms-like tyrosine kinase-1 (sFlt-1, also referred to as sVEGFR-1). sFlt-1 is an endogenous anti-angiogenic protein that is made by the placenta and acts by neutralizing the pro-angiogenic proteins vascular endothelial growth factor (VEGF) and placental growth factor (PIGF). More recently, soluble endoglin, another circulating anti-angiogenic protein was found to synergize with sFlt1 and contribute to the pathogenesis of preeclampsia. Abnormalities in these circulating angiogenic proteins are not only present during clinical preeclampsia, but also antedate clinical symptoms by several weeks. This review will summarize our current understanding of the molecular mechanism of preeclampsia, with an emphasis on the recently characterized circulating anti-angiogenic proteins.
\end{abstract}

\section{Introduction}

Preeclampsia is a disease of pregnancy characterized by hypertension and proteinuria developing after 20 weeks of gestation. It has been estimated that 5 to $7 \%$ of pregnancies world wide are complicated by this disorder resulting in a very large disease burden (Sibai et al., 2003; Walker, 2000; Zhang et al., 2003). Potential fetal complications include low birth weight, prematurity and death. Maternal complications include renal failure, HELLP syndrome (hemolysis, elevated liver enzymes, and thrombocytopenia), liver failure, cerebral edema with seizures and rarely death.

Until recently most work on the disease has focused on abnormal placentation, genetic and epidemiologic factors, as well as treatments aimed at slowing the progression of the disease. Nephrologists have been interested in the condition because of the prominence of proteinuria in the clinical presentation and the unique pathologic changes in the kidney. In the last few years, however, new discoveries suggest that preeclampsia is in fact related to an imbalance of circulating angiogenic factors resulting in endothelial dysfunction. The implication of this theory is that preeclampsia is primarily a disease of the vascular endothelium. Notably, risk

Address for Correspondence: S. Ananth Karumanchi, M.D., Beth Israel Deaconess Medical Center, Molecular and Vascular Medicine, RW 663, 330 Brookline Avenue, Boston, MA 02215, Tel: 617-667-1018, Fax: 617-667-2913, E-mail: sananth@bidmc.harvard.edu.

Disclosures

S.A.K is listed as a co-inventor on multiple patents filed by the Beth Israel Deaconess Medical Center for the use of angiogenic proteins for the diagnosis and therapy of preeclampsia. S.A.K. is a consultant to Johnson \& Johnson, Beckman Coulter and Abbott Diagnostics.

Publisher's Disclaimer: This is a PDF file of an unedited manuscript that has been accepted for publication. As a service to our customers we are providing this early version of the manuscript. The manuscript will undergo copyediting, typesetting, and review of the resulting proof before it is published in its final citable form. Please note that during the production process errors may be discovered which could affect the content, and all legal disclaimers that apply to the journal pertain. 
factors for preeclampsia include maternal obesity, insulin resistance, hyperlipidemia, hypertension, kidney disease and thrombophilias which may be markers for underlying vascular disease (Said and Dekker, 2003; Thadhani et al., 2004; Thadhani et al., 1999; Wolf et al., 2001; Wolf et al., 2002). Preeclampsia thus warrants the close attention of vascular biologists as further investigation of this disease will no doubt shed light on endothelial function in general.

Traditionally, preeclampsia has been viewed as a self limited condition that resolves after delivery of the placenta with little long term sequelae for the mother, although fetal morbidity may be great. However, recent data has shown that maternal endothelial dysfunction may persist years after the episode, and women who have suffered from preeclampsia may be at higher risk for cardiovascular events in the future. For example, Doppler studies of brachial artery reactivity in women who have had preeclampsia shows abnormal endothelial dependent flow-mediated arterial dilation three years after pregnancy (Chambers et al., 2001).

In this review we highlight some of the recent advances in our understanding of the impaired placentation, describe the imbalance of angiogenic and anti-angiogenic factors which confer the disease phenotype, and conclude with potential future applications for diagnosis and treatment. While anti-angiogenic therapy is now seeing success in cancer therapy, preeclampsia provides an interesting example where pro-angiogenic therapies aimed at repairing disturbed endothelial function may be useful.

\section{Background}

The constellation of clinical findings of preeclampsia has only been observed in pregnant women leading to the conclusion that a placenta is necessary. Preeclampsia has been observed in patients with molar pregnancy where a fetus is absent demonstrating that the placenta is also sufficient to cause the condition. Interestingly, the fetus does not develop clinical findings similar to the maternal syndrome and fetal morbidity and mortality is believed to result exclusively from placental insufficiency. In almost all cases, the disease regresses shortly after delivery of the placenta, but may persist if placental tissue is retained. These observations have led investigators to speculate that there may be a circulating factor (or factors) produced by the placenta that contribute to the maternal disease. Work to date has shown that the placenta of women with preeclampsia is abnormally developed and probably relatively hypoxic. Maternal endothelial dysfunction, possibly related to circulating factors elaborated from the abnormal placenta, is a key feature (Roberts et al., 1989).

Disordered vascular endothelial function seems to be important. Women with preeclampsia demonstrate increased sympathetic tone (Schobel et al., 1996), increased pressor response to norepinephirne (Chesley et al., 1965) and are more sensitive to angiotensin II (Gant et al., 1973). There are also alterations in endothelial derived vasoactive mediators such as decreased amounts of the vasodilators prostaglandin $\mathrm{I}_{2}\left(\mathrm{PGI}_{2}\right)$ (Baker et al., 1996) and nitric oxide (Williams et al., 1997) as well as increased amounts of the vasoconstrictors thromboxane $\mathrm{A}_{2}$ (Mills et al., 1999) and endothelin (Clark et al., 1992). Historically the search for a secreted placental factor has been hampered by lack of a suitable animal model and a plausible mechanism to explain all of the disease manifestations. On the other hand, human placental tissue is readily available and much work has been done to characterize the changes in placentation unique to preeclampsia. Recently, mRNA microarray of placental tissue from patients with preeclampsia has identified increased amounts of at least two circulating proteins that may play an important part in the pathogenesis of the disease. These proteins, soluble fmslike kinase 1 (sFlt-1) and soluble endoglin (sEng) contribute to endothelial dysfunction, reproduce the clinical syndrome in a rat model and may predict the onset of the disease 
(Maynard et al., 2003; Venkatesha et al., 2006). Most importantly they provide potential targets for therapy.

\section{Disordered Placentation}

The placenta is essential for exchange of nutrients, oxygen and waste between the mother and the developing fetus. Coordinated vascularization of the placenta is essential for the proper placental development and involves the processes of vasculogenesis (new blood vessel formation) and angiogenesis (growth of blood vessels) (Cross et al., 1994). Normal placentation is thought to involve a two stage process including the formation of a branching network of vessels within the chorionic villi of fetal origin followed later by modification of the existing vascular network and transformation from a high resistance relatively hypoxic vascular bed into a low resistance circuit with increased oxygen tension (Cross et al., 1994; Kaufmann et al., 1985; Leiser et al., 1985).

Two to three weeks after conception the placenta is composed of primary villi which are columnar structures consisting of cytotrophoblast cells surrounded by a layer of syncytiotrophoblast. Mesenchymal cells later invade the villi forming secondary villi and give rise to placental blood vessels. Mesenchymal derived machrophaes (Hofbauer cells) express VEGF and other angiogenic factors and are thought to initiate vasculogenesis in the placenta (Ahmed et al., 2000; Ahmed et al., 1995; Demir et al., 1989). Later in placental development, additional capillaries form by branching angiogenesis from pre-existing capillaries.

A key event in normal placentation is invasion of the maternal spiral arteries in the decidua and myometrium by fetal cytotrophoblasts. Extensive work by Susan Fisher's group has shown that this process is defective in preeclamptic placentas (Damsky and Fisher, 1998; Zhou et al., 2003a; 1997a; 1997b; 2003b). Normally trophoblast cells transform from an epithelial phenotype to an endothelial phenotype as they invade the maternal deciduas and myometrium in a process termed pseudovasculogenesis. They express markers such as vascular endothelialcadherin (VE-cadherin), and alpha beta $_{3}$ integrin (Zhou et al., 1997a). These migrating trophoblasts transform the maternal spiral arterioles that supply maternal blood to the placenta from small caliber resistance vessels to large caliber capacitance vessels allowing adequate maternal blood flow to the placenta. In preeclampsia this process is disordered and the fetal trophoblasts fail to properly invade the maternal myometrium and spiral arterioles (Brosens et al., 1972). Normally, early placental development occurs in a hypoxic environment and the placenta becomes increasingly oxygenated with time (Genbacev et al., 1997). It has been theorized that this failure of conversion of spiral arterioles results in persistent placental hypoxia, placental insufficiency and ultimately maternal endothelial dysfunction and the clinical syndrome of preeclampsia.

\section{Identification of Circulating Factors}

Endothelial dysfunction is thought to contribute to the clinical syndrome of preeclampsia (Roberts and Cooper, 2001). Hallmarks of the disease include arterial hyperreactivity to exogenous and endogenous stimuli, proteinuria related to increased glomerular permeability, cerebral edema and increased CNS permeability, as well as vascular thrombosis resulting in the (HELLP) syndrome all of which may result from disordered endothelial function (Roberts, 1998; Roberts and Cooper, 2001). Studies have shown increased endothelial cell permeability, lipid peroxidation (Hubel et al., 1996), platelet activation (Kolben et al., 1995; Kolben et al., 1996) and oxidative stress (Davidge, 1998). Several investigators have hypothesized that a circulating factor or factors, probably elaborated by the placenta, cause the maternal disease (Ferris, 1991; Roberts et al., 1989). Serum from patients with preeclampsia show increased levels of circulating factors associated with endothelial injury including fibronectin, factor VIII antigen, and thrombomodulin (Friedman et al., 1995; Hsu et al., 1993; Taylor et al., 1991). 
Also, patients with preeclampsia show abnormal arterial vessel endothelial function even before the onset of disease (Cockell and Poston, 1997; McCarthy et al., 1993; Savvidou et al., 2003). Additional data supporting endothelial dysfunction includes decreased generation of endothelins, diminished production of endothelium-derived vasodilators such as prostacyclins and increased vascular sensitivity to angiotensin II and norepinephrine mediated vascular constriction (Clark et al., 1992; Gant et al., 1973; Gant et al., 1987; Mills et al., 1999).

There has been an active search for circulating factors that cause or contribute to endothelial dysfunction. Variation in the serum levels of sevaral substances that may alter endothelial function have been demonstrated including TNF-alpha, interlukin (IL)-6, IL-1alpha, IL-1beta, Fas ligand, oxidized lipid products, neruokinin B, and asymmetric dimethylarginine (Benyo et al., 2001; Conrad et al., 1998; Page et al., 2000; Savvidou et al., 2003) although it is not clear if these variations are causal or simply an epiphenomenon. Bradykinin (B2) receptors are up-regulated in preeclampsia and my heterodimreize with angiotensin II type 1 receptors and increase responsiveness to angoitensin II in vitro (AbdAlla et al., 2001). Interestingly, antibodies to angiotensin receptor-1 have been identified in humans with preeclampsia as well as in an transgenic rat model of the disease and may augment the normal response to angiotensin II (Dechend et al., 2005; Dechend et al., 2000; Roberts and Cooper, 2001; Wallukat et al., 1999). However, they have not been shown to reproduce the entire phenotype of preeclampsia or antedate the onset of disease.

\section{Soluble Fms-like Tyrosine Kinase-1 (sFIt-1)}

Recent work by our group and others has demonstrated increased placental production and maternal serum levels of sFlt-1 in patients with preeclampsia (Ahmad and Ahmed, 2004; Chaiworapongsa et al., 2004; Koga et al., 2003; Maynard et al., 2003; Shibata et al., 2005). sFlt-1 is an alternatively spliced and truncated version of vascular endothelial growth factor receptor 1 (VEGF-R1). It contains the extracellular ligand-binding domain but lacks the transmembrane and cytoplasmic portions of VEGF-R1 (He et al., 1999; Kendall and Thomas, 1993). sFlt-1 is able to bind both VEGF and PIGF. Free in serum, it may diminish binding of these growth factors to their cognate receptors VEGF-R1 and VEGF-R2 also known as fmslike tyrosine kinse-1 (Flt-1) and kinase domain region (Flk/KDR) respectively (Kendall et al., 1996). The placenta is known to produce a number of other angiogenic factors including VEGF, PlGF, the angiopoietis (Ang-1 and Ang-2) as well as their receptor Tie-2 (Dunk et al., 2000; Geva et al., 2002; Goldman-Wohl et al., 2000).

In patients with preeclampsia, increased sFlt-1 is associated with decreased free VEGF and PlGF in the serum. Using an adenoviral vector, sFlt-1 has been overexpressed in pregnant rats (Maynard et al., 2003). The animals developed proteinuria, hypertension and glomerular endotheliosis which are hallmarks of preeclampsia. Notably the phenotype was also present in non-pregnant animals expressing sFlt-1. When soluble VEGF receptor-2 (sFlk-1), which antagonizes VEGF but not PIGF, was overexpressed in pregnant rats they did not develop changes consistent with preeclampsia arguing that antagonism of both VEGF and PIGF is necessary to reproduce the disease (Maynard et al., 2003). Antibodies against VEGF or sFlt-1 protein has also been shown to induce glomerular endothelial damage with proteinuria in nonpregnant mice (Kitamoto et al., 2001; Sugimoto et al., 2003).

There is strong evidence to suggest that the capillary endothelium of the kidney, for example, is extremely sensitive to VEGF which is produced locally by the visceral epithelium (podocytes) and may explain why renal dysfunction is an important and early marker of the disease. VEGF is necessary to maintain the normal fenestration of glomerular endothelial cells (Ballermann, 2005; Maharaj et al., 2006). In non-pregnant mice a 50\% reduction of VEGF leads to glomerular endotheliosis and proteinuria similar to what is seen in preeclampsia 
(Eremina et al., 2003). In addition, it has been reported that patients receiving VEGF antagonists for cancer treatment may develop hypertension, proteinuria and endothelial activation (Kabbinavar et al., 2003; Kuenen et al., 2002; Yang et al., 2003). In preeclampsia it is likely that VEGF signaling is decreased in the kidney due to excess sFlt-1 leading to the glomerular changes of endotheliosis and proteinuria.

\section{Regulation of sFlt-1 and Placental Hypoxia}

Much work has been done regarding placental ischemia/hypoxia and its possible role in preeclampsia. Clinical data shows that women who develop preeclampsia have decreased uteroplacental blood flow (Lunell et al., 1984). Hypoxic conditions are known to stimulate expression of a number of pro-angiogenic proteins in endothelial and tumor cells including endothelin (Kourembanas et al., 1991) VEGF (Shweiki et al., 1992) and Flt-1 (Gerber et al., 1997). The transcription factor hypoxia-inducible factor 1 (HIF1 alpha) regulates VEGF and Flt-1 gene transcription (Forsythe et al., 1996; Gerber et al., 1997) and importantly HIF-1 alpha and HIF-2 alpha protein levels are significantly elevated in the preeclamptic placenta (Caniggia et al., 2000; Rajakumar et al., 2003; Rajakumar et al., 2001). Lowered oxygen tension in primary cytotrophoblast culture and villous explants causes increased sFlt-1 expression suggesting that sFlt expression may be stimulated by hypoxia (Ahmad and Ahmed, 2004; Nagamatsu et al., 2004). As predicted VEGF expression was also increased but free VEGF and PIGF in the supernatant were low suggesting that the sFlt-1 induction exceeded VEGF production resulting in a net anti-angiogenic state. Furthermore, there is increased expression of sFlt-1 noted both in vitro and in vivo models of placental hypoxia (Nevo et al., 2006). More recently, it has been reported that uteroplacental ischemia induced in primates results in preeclampsia-like phenotype that was accompanied by elevated circulating sFlt-1 (Makris et al., 2007). Collectively, these data suggest that placental ischemia/hypoxia may alone be sufficient to induce preeclampsia through sFlt-1 up-regulation. Whether placental ischemia is necessary for the induction of human preeclampsia is still unknown.

It has also been reported that heme oxygenase -1 via carbon monoxide may be a negative regulator of sFlt-1 production in the placenta (Cudmore et al., 2007). These findings may have explain the clinical observation that the incidence of preeclampsia is lower in smokers who are exposed to high levels of carbon monoxide (England et al., 2003).

\section{Does sFIt-1 predict the onset of preeclampsia?}

The hypothesis that preeclampsia may be caused by an imbalance of circulating angiogenic factors suggests that these changes may precede the onset of clinical disease and may be useful in designing screening and/or diagnostic tests to identify patients at risk for preeclampsia. Such a test would be invaluable to clinicians who may offer close follow-up and therapeutic interventions early in the course of disease. Several retrospective studies using preeclamptic serum have shown that sFlt-1 concentrations in serum are high as much as five to six weeks before any clinical findings are noted (Chaiworapongsa et al., 2005; Hertig et al., 2004; Levine et al., 2004; McKeeman et al., 2004). In addition, free VEGF and PIGF are low (Hertig et al., 2004; Levine et al., 2004) and may predict the onset of disease. Urinary markers are convenient in that they do not require venopuncture and one study has shown decreased urinary PlGF prior to the development of clinical preeclampsia (Levine et al., 2005). A recent systematic review of the literature to assess if elevated sFlt- 1 or decreased PIGF in the serum could accurately predict the onset of preelcampsia concluded that third trimester increases in sFlt- 1 and decreases in PIGF are associated with preeclampsia but there is currently insufficient data to recommend these as screening tests (Widmer et al., 2007). The authors recommended well constructed and rigorous prospective trials to determine the clinical usefulness of these tests. 


\section{Additional Circulating Factors}

Although overexpression of sFlt-1 reproduces the clinical changes of preeclampsia in rats, and elevated levels of sFlt-1 associated with decreased lfree VEGF and PIGF are present prior to the onset of preeclampsia, sFlt-1 excess is probably not sufficient to explain all the manifestations of the disease. For example, rats expressing very high levels of sFlt-1 do not develop coagulation abnormalities, liver dysfunction or seizures which may be seen in the human disease.

Recently, attention has focused on endoglin (Eng), a co-receptor for transforming growth factor $\beta 1$ and $\beta 3$, and a protein expressed in large quantities by the placenta in preeclampsia. Endoglin is highly expressed in vascular endothelial cells (Cheifetz et al., 1992) and syncytiotrophoblasts (Gougos et al., 1992). It regulates vascular tone through interactions with endothelial nitric oxide synthase (Toporsian et al., 2005). The extra-cellular domain of endoglin may be shed and is found in the serum where it is referred to as soluble endoglin (sEng). sEng inhibits endothelial capillary tube formation and promotes vascular permeability (Venkatesha et al., 2006). When overexpressed by adenoviral vector in rats, sEng causes proteinuria and hypertension that are more mild then seen with sFlt-1 overexpression alone. However, when sEng is co-expressed with sFlt- 1 , the rats develop severe proteinuria, hypertension, intrauterine growth restriction as well as low platelets and elevated LDH similar to human HELLP syndrome (Venkatesha et al., 2006). Like sFlt-1, sEng is increased in maternal serum two to three months prior to the onset of disease (Levine et al., 2006). sEng and sFlt-1 both cause endothelial dysfunction by different mechanisms but may cooperate to produce the clinical syndrome of preeclampsia.

\section{Persistent Maternal Endothelial Dysfunction}

Women who have had preeclampsia are at higher risk for developing chronic hypertension, coronary artery disease, and stroke. It remains unknown if this represents the presence of risk factors that predispose to both preeclampsia and vascular disease including obesity, hypertension, and insulin resistance or if a history of preeclampsia confers a new risk factor for later vascular disease. For example, the CHAMPS study found an increased risk of hospital admissions or arterial revascularization in women who had a history of preeclampsia compared with controls (Ray et al., 2005). Another retrospective study showed an 8.1 fold increased risk of cardiovascular death in women who had preeclampsia and delivered prior to 37 weeks gestation (Irgens et al., 2001).

It is plausible that preeclampsia may reflect an underlying predisposition to developing vascular disease later in life. Some have suggested that it may serve as an endothelial "stress test" unmasking those with a predisposition to endothelial and vascular dysfunction. One study that attempted to control for underlying genetic and environmental factors found that women with preeclampsia were more likely to develop hypertension then non-preeclamptic siblings (Irgens et al., 2001). A recent study showed that women with preeclampsia were more likely to have impaired brachial artery endothelium-mediated vasodilation up to two years after delivery. They also had lower serum nitrates and higher cholesterol compared with controls (Germain et al., 2007).

A provocative theory posits that women with a history of preeclampsia have a residual antiangiogenic balance and may be somewhat protected from growth of solid tumors which rely on VEGF and other angiogenic factors for neovascularization, tumor growth and metastasis. In fact some studies (Cohn et al., 2001; Vatten et al., 2002), although not all (Paltiel et al., 2004) have shown a decreased incidence of breast cancer in women with a history of preeclampsia. There is also evidence to suggest a lower incidence of other solid tumors (Aagaard-Tillery et al., 2006). 


\section{Implications for Therapy}

The implications of these advances on our clinical management of preeclampsia may be profound. Pharmacological intervention aimed at restoring the angiogenic balance may prevent or modify the course of preeclampsia. The availability of reliable animal models that closely mimics human preeclampsia should allow rapid testing of novel therapeutic compounds. In this regard, VEGF-121 (an isoform of VEGF) has been recently shown to ameliorate preeclamptic signs and symptoms in a rat model of preeclampsia (Steve Pollitt and Ananth Karumanchi, unpublished observations). Safely prolonging pregnancy by only a few weeks could substantially reduce maternal and neonatal morbidity and mortality resulting from preeclampsia.

\section{Conclusions}

Preeclampsia is a condition characterized by systemic vascular endothelial dysfunction. It is associated with elevated levels of markers of endothelial damage in the serum as well as impaired vascular homeostasis. sFlt-1, a soluble version of the VEGF receptor 1, is present in high quantities in the serum of women with preeclampsia and is associated with low levels of free VEGF and PlGF. Overexpression of sFlt-1 in rats reproduces a phenotype that is very similar to human preeclampsia. Increased levels of sFlt-1 have been documented in women several weeks before the onset of clinical disease in conjunction with decreased levels of free PlGF and predict the onset of clinical symptoms. It is not yet clear if abnormal sFlt-1 production is a cause or consequence of abnormal placentation and specifically how placental hypoxia caused by disordered vasculogenesis contributes to the disease. An additional anti-angiogenic protein, sEng, is also produced in high quantities by the placenta and seems to cooperate with sFlt-1 in a rat model to produce a severe form of the condition similar to HELLP syndrome. Moreover, sEng levels rise in maternal serum several months before the onset of preeclampsia and may be particularly useful to predict those patients who will develop a more severe form of the disease. Future studies focusing on the regulation of angiogenic gene products and their role in placental angiogenesis and systemic vascular health will lead to a better understanding of the pathogenesis of preeclampsia as well as better therapeutic options.

\section{Acknowledgements}

S.A.K. is funded by R01 grants from the National Institute of Diabetes, Digestive and Kidney Diseases (DK 065997) and the National Heart, Lung, and Blood Institute (HL079594).

\section{References}

Aagaard-Tillery KM, Stoddard GJ, Holmgren C, Lacoursiere DY, Fraser A, Mineau GP, Varner MW. Preeclampsia and subsequent risk of cancer in Utah. Am J Obstet Gynecol 2006;195:691-699. [PubMed: 16949398]

AbdAlla S, Lother H, el Massiery A, Quitterer U. Increased AT(1) receptor heterodimers in preeclampsia mediate enhanced angiotensin II responsiveness. Nat Med 7:1003-1009. [PubMed: 11533702]

Ahmad S, Ahmed A. Elevated placental soluble vascular endothelial growth factor receptor-1 inhibits angiogenesis in preeclampsia. Circ Res 2004;95:884-891. [PubMed: 15472115]

Ahmed A, Dunk C, Ahmad S, Khaliq A. Regulation of placental vascular endothelial growth factor (VEGF) and placenta growth factor (PIGF) and soluble Flt-1 by oxygen--a review. Placenta 2000;21 (Suppl A):S16-24. [PubMed: 10831117]

Ahmed A, Li XF, Dunk C, Whittle MJ, Rushton DI, Rollason T. Colocalisation of vascular endothelial growth factor and its Flt-1 receptor in human placenta. Growth Factors 1995;12:235-243. [PubMed: 8619929]

Baker PN, Davidge ST, Barankiewicz J, Roberts JM. Plasma of preeclamptic women stimulates and then inhibits endothelial prostacyclin. Hypertension 1996;27:56-61. [PubMed: 8591888] 
Ballermann BJ. Glomerular endothelial cell differentiation. Kidney Int 2005;67:1668-1671. [PubMed: 15840009]

Benyo DF, Smarason A, Redman CW, Sims C, Conrad KP. Expression of inflammatory cytokines in placentas from women with preeclampsia. J Clin Endocrinol Metab 2001;86:2505-2512. [PubMed: 11397847]

Brosens IA, Robertson WB, Dixon HG. The role of the spiral arteries in the pathogenesis of preeclampsia. Obstet Gynecol Annu 1972;1:177-191. [PubMed: 4669123]

Caniggia I, Winter J, Lye SJ, Post M. Oxygen and placental development during the first trimester: implications for the pathophysiology of pre-eclampsia. Placenta 2000;21(Suppl A):S25-30. [PubMed: 10831118]

Chaiworapongsa T, Romero R, Espinoza J, Bujold E, Mee Kim Y, Goncalves LF, Gomez R, Edwin S. Evidence supporting a role for blockade of the vascular endothelial growth factor system in the pathophysiology of preeclampsia Young Investigator Award. Am J Obstet Gynecol 2004;190:15411547. [PubMed: 15284729]discussion 1547-1550

Chaiworapongsa T, Romero R, Kim YM, Kim GJ, Kim MR, Espinoza J, Bujold E, Goncalves L, Gomez R, Edwin S, Mazor M. Plasma soluble vascular endothelial growth factor receptor-1 concentration is elevated prior to the clinical diagnosis of preeclampsia. J Matern Fetal Neonatal Med 2005;17:318. [PubMed: 15804781]

Chambers JC, Fusi L, Malik IS, Haskard DO, De Swiet M, Kooner JS. Association of maternal endothelial dysfunction with preeclampsia. Jama 2001;285:1607-1612. [PubMed: 11268269]

Cheifetz S, Bellon T, Cales C, Vera S, Bernabeu C, Massague J, Letarte M. Endoglin is a component of the transforming growth factor-beta receptor system in human endothelial cells. J Biol Chem 1992;267:19027-19030. [PubMed: 1326540]

Chesley LC, Talledo E, Bohler CS, Zuspan FP. Vascular Reactivity to Angiotensin Ii and Norepinephrine in Pregnant Women. Am J Obstet Gynecol 1965;91:837-842. [PubMed: 14261040]

Clark BA, Halvorson L, Sachs B, Epstein FH. Plasma endothelin levels in preeclampsia: elevation and correlation with uric acid levels and renal impairment. Am J Obstet Gynecol 1992;166:962-968. [PubMed: 1532292]

Cockell AP, Poston L. Flow-mediated vasodilatation is enhanced in normal pregnancy but reduced in preeclampsia. Hypertension 1997;30:247-251. [PubMed: 9260988]

Cohn BA, Cirillo PM, Christianson RE, van den Berg BJ, Siiteri PK. Placental characteristics and reduced risk of maternal breast cancer. J Natl Cancer Inst 2001;93:1133-1140. [PubMed: 11481384]

Conrad KP, Miles TM, Benyo DF. Circulating levels of immunoreactive cytokines in women with preeclampsia. Am J Reprod Immunol 1998;40:102-111. [PubMed: 9764352]

Cross JC, Werb Z, Fisher SJ. Implantation and the placenta: key pieces of the development puzzle. Science 1994;266:1508-1518. [PubMed: 7985020]

Cudmore M, Ahmad S, Al-Ani B, Fujisawa T, Coxall H, Chudasama K, Devey LR, Wigmore SJ, Abbas A, Hewett PW, Ahmed A. Negative regulation of soluble Flt-1 and soluble endoglin release by heme oxygenase-1. Circulation 2007;115:1789-1797. [PubMed: 17389265]

Damsky CH, Fisher SJ. Trophoblast pseudo-vasculogenesis: faking it with endothelial adhesion receptors. Curr Opin Cell Biol 1998;10:660-666. [PubMed: 9818178]

Davidge ST. Oxidative stress and altered endothelial cell function in preeclampsia. Semin Reprod Endocrinol 1998;16:65-73. [PubMed: 9654609]

Dechend R, Gratze P, Wallukat G, Shagdarsuren E, Plehm R, Brasen JH, Fiebeler A, Schneider W, Caluwaerts S, Vercruysse L, et al. Agonistic autoantibodies to the AT1. receptor in a transgenic rat model of preeclampsia. Hypertension 2005;45:742-746. [PubMed: 15699466]

Dechend R, Homuth V, Wallukat G, Kreuzer J, Park JK, Theuer J, Juepner A, Gulba DC, Mackman N, Haller H, Luft FC. AT(1) receptor agonistic antibodies from preeclamptic patients cause vascular cells to express tissue factor. Circulation 2000;101:2382-2387. [PubMed: 10821814]

Demir R, Kaufmann P, Castellucci M, Erbengi T, Kotowski A. Fetal vasculogenesis and angiogenesis in human placental villi. Acta Anat (Basel) 1989;136:190-203. [PubMed: 2481376]

Dunk C, Shams M, Nijjar S, Rhaman M, Qiu Y, Bussolati B, Ahmed A. Angiopoietin-1 and angiopoietin-2 activate trophoblast Tie-2 to promote growth and migration during placental development. Am J Pathol 2000;156:2185-2199. [PubMed: 10854239] 
England LJ, Levine RJ, Mills JL, Klebanoff MA, Yu KF, Cnattingius S. Adverse pregnancy outcomes in snuff users. Am J Obstet Gynecol 2003;189:939-943. [PubMed: 14586330]

Eremina V, Sood M, Haigh J, Nagy A, Lajoie G, Ferrara N, Gerber HP, Kikkawa Y, Miner JH, Quaggin SE. Glomerular-specific alterations of VEGF-A expression lead to distinct congenital and acquired renal diseases. J Clin Invest 2003;111:707-716. [PubMed: 12618525]

Ferris TF. Pregnancy, preeclampsia and the endothelial cell. N Engl J Med 1991;325:1439-1440. [PubMed: 1922256]

Forsythe JA, Jiang BH, Iyer NV, Agani F, Leung SW, Koos RD, Semenza GL. Activation of vascular endothelial growth factor gene transcription by hypoxia-inducible factor 1. Mol Cell Biol 1996;16:4604-4613. [PubMed: 8756616]

Friedman SA, Schiff E, Emeis JJ, Dekker GA, Sibai BM. Biochemical corroboration of endothelial involvement in severe preeclampsia. Am J Obstet Gynecol 1995;172:202-203. [PubMed: 7847535]

Gant NF, Daley GL, Chand S, Whalley PJ, MacDonald PC. A study of angiotensin II pressor response throughout primigravid pregnancy. J Clin Invest 1973;52:2682-2689. [PubMed: 4355997]

Gant NF, Whalley PJ, Everett RB, Worley RJ, MacDonald PC. Control of vascular reactivity in pregnancy. Am J Kidney Dis 1987;9:303-307. [PubMed: 3555002]

Genbacev O, Zhou Y, Ludlow JW, Fisher SJ. Regulation of human placental development by oxygen tension. Science 1997;277:1669-1672. [PubMed: 9287221]

Gerber HP, Condorelli F, Park J, Ferrara N. Differential transcriptional regulation of the two vascular endothelial growth factor receptor genes. Flt-1, but not Flk-1/KDR, is up-regulated by hypoxia. J Biol Chem 1997;272:23659-23667. [PubMed: 9295307]

Germain AM, Romanik MC, Guerra I, Solari S, Reyes MS, Johnson RJ, Price K, Karumanchi SA, Valdes G. Endothelial dysfunction: a link among preeclampsia, recurrent pregnancy loss, and future cardiovascular events. Hypertension 2007;49:90-95. [PubMed: 17116761]

Geva E, Ginzinger DG, Zaloudek CJ, Moore DH, Byrne A, Jaffe RB. Human placental vascular development: vasculogenic and angiogenic (branching and nonbranching) transformation is regulated by vascular endothelial growth factor-A, angiopoietin-1, and angiopoietin-2. J Clin Endocrinol Metab 2002;87:4213-4224. [PubMed: 12213874]

Goldman-Wohl DS, Ariel I, Greenfield C, Lavy Y, Yagel S. Tie-2 and angiopoietin-2 expression at the fetal-maternal: interface a receptor ligand model for vascular remodelling. Mol Hum Reprod 2000;6:81-87. [PubMed: 10611265]

Gougos A, St Jacques S, Greaves A, O'Connell P, d'Apice AJ, Buhring HJ, Bernabeu C, van Mourik JA, Letarte M. Identification of distinct epitopes of endoglin, an RGD-containing glycoprotein of endothelial cells, leukemic cells and syncytiotrophoblasts. Int Immunol 1992;4:83-92. [PubMed: 1371694]

He Y, Smith SK, Day KA, Clark DE, Licence DR, Charnock-Jones DS. Alternative splicing of vascular endothelial growth factor (VEGF)-R1 (FLT-1) pre-mRNA is important for the regulation of VEGF activity. Mol Endocrinol 1999;13:537-545. [PubMed: 10194760]

Hertig A, Berkane N, Lefevre G, Toumi K, Marti HP, Capeau J, Uzan S, Rondeau E. Maternal serum sFlt 1 concentration is an early and reliable predictive marker of preeclampsias. Clin Chem 2004;50:1702-1703. [PubMed: 15331514]

Hsu CD, Iriye B, Johnson TR, Witter FR, Hong SF, Chan DW. Elevated circulating thrombomodulin in severe preeclampsia. Am J Obstet Gynecol 1993;169:148-149. [PubMed: 8392790]

Hubel CA, McLaughlin MK, Evans RW, Hauth BA, Sims CJ, Roberts JM. Fasting serum triglycerides, free fatty acids, and malondialdehyde are increased in preeclampsia, are positively correlated, and decrease within 48 hours post partum. Am J Obstet Gynecol 1996;174:975-982. [PubMed: 8633679]

Irgens HU, Reisaeter L, Irgens LM, Lie RT. Long term mortality of mothers and fathers after preeclampsia: population based cohort study. Bmj 2001;323:1213-1217. [PubMed: 11719411]

Kabbinavar F, Hurwitz HI, Fehrenbacher L, Meropol NJ, Novotny WF, Lieberman G, Griffing S, Bergsland E. Phase II, randomized trial comparing bevacizumab plus fluorouracil (FU)/leucovorin (LV) with FU/LV alone in patients with metastatic colorectal cancer. J Clin Oncol 2003;21:60-65. [PubMed: 12506171] 
Kaufmann P, Bruns U, Leiser R, Luckhardt M, Winterhager E. The fetal vascularisation of term human placental villi. II. Intermediate and terminal villi. Anat Embryol (Berl) 1985;173:203-214. [PubMed: 4083522]

Kendall RL, Thomas KA. Inhibition of vascular endothelial cell growth factor activity by an endogenously encoded soluble receptor. Proc Natl Acad Sci U S A 1993;90:10705-10709. [PubMed: 8248162]

Kendall RL, Wang G, Thomas KA. Identification of a natural soluble form of the vascular endothelial growth factor receptor, FLT-1 and its heterodimerization with KDR. Biochem Biophys Res Commun 1996;226:324-328. [PubMed: 8806634]

Kitamoto Y, Takeya M, Tokunaga H, Tomita K. Glomerular endothelial cells are maintained by vascular endothelial growth factor in the adult kidney. Tohoku J Exp Med 2001;195:43-54. [PubMed: 11780723]

Koga K, Osuga Y, Yoshino O, Hirota Y, Ruimeng X, Hirata T, Takeda S, Yano T, Tsutsumi O, Taketani Y. Elevated serum soluble vascular endothelial growth factor receptor 1 (sVEGFR-1) levels in women with preeclampsia. J Clin Endocrinol Metab 2003;88:2348-2351. [PubMed: 12727995]

Kolben M, Lopens A, Blaser J, Huber A, Frank M, Wilhelm O, Wilhelm S, Schneider KT, Ulm K, Tschesche $\mathrm{H}$, et al. [Measuring the concentration of various plasma and placenta extract proteolytic and vascular factors in pregnant patients with HELLP syndrome, pre-/eclampsia and highly pathologic Doppler flow values]. Gynakol Geburtshilfliche Rundsch 1995;35(Suppl 1):126-131. [PubMed: 8672911]

Kolben M, Lopens A, Blaser J, Ulm K, Schmitt M, Schneider KT, Tschesche H. Proteases and their inhibitors are indicative in gestational disease. Eur J Obstet Gynecol Reprod Biol 1996;68:59-65. [PubMed: 8886683]

Kourembanas S, Marsden PA, McQuillan LP, Faller DV. Hypoxia induces endothelin gene expression and secretion in cultured human endothelium. J Clin Invest 1991;88:1054-1057. [PubMed: 1885767]

Kuenen BC, Levi M, Meijers JC, Kakkar AK, van Hinsbergh VW, Kostense PJ, Pinedo HM, Hoekman $\mathrm{K}$. Analysis of coagulation cascade and endothelial cell activation during inhibition of vascular endothelial growth factor/vascular endothelial growth factor receptor pathway in cancer patients. Arterioscler Thromb Vasc Biol 2002;22:1500-1505. [PubMed: 12231573]

Leiser R, Luckhardt M, Kaufmann P, Winterhager E, Bruns U. The fetal vascularisation of term human placental villi. I. Peripheral stem villi. Anat Embryol (Berl) 1985;173:71-80. [PubMed: 4073533]

Levine RJ, Lam C, Qian C, Yu KF, Maynard SE, Sachs BP, Sibai BM, Epstein FH, Romero R, Thadhani R, Karumanchi SA. Soluble endoglin and other circulating antiangiogenic factors in preeclampsia. N Engl J Med 2006;355:992-1005. [PubMed: 16957146]

Levine RJ, Maynard SE, Qian C, Lim KH, England LJ, Yu KF, Schisterman EF, Thadhani R, Sachs BP, Epstein $\mathrm{FH}$, et al. Circulating angiogenic factors and the risk of preeclampsia. N Engl J Med 2004;350:672-683. [PubMed: 14764923]

Levine RJ, Thadhani R, Qian C, Lam C, Lim KH, Yu KF, Blink AL, Sachs BP, Epstein FH, Sibai BM, et al. Urinary placental growth factor and risk of preeclampsia. Jama 2005;293:77-85. [PubMed: 15632339]

Lunell NO, Lewander R, Mamoun I, Nylund L, Sarby S, Thornstrom S. Uteroplacental blood flow in pregnancy induced hypertension. Scand J Clin Lab Invest Suppl 1984;169:28-35. [PubMed: 6593815]

Maharaj AS, Saint-Geniez M, Maldonado AE, D'Amore PA. Vascular endothelial growth factor localization in the adult. Am J Pathol 2006;168:639-648. [PubMed: 16436677]

Makris A, Thornton C, Thompson J, Thomson S, Martin R, Ogle R, Waugh R, McKenzie P, Kirwan P, Hennessy A. Uteroplacental ischemia results in proteinuric hypertension and elevated sFLT-1. Kidney Int. 2007

Maynard SE, Min JY, Merchan J, Lim KH, Li J, Mondal S, Libermann TA, Morgan JP, Sellke FW, Stillman IE, et al. Excess placental soluble fms-like tyrosine kinase 1 (sFlt1) may contribute to endothelial dysfunction, hypertension, and proteinuria in preeclampsia. J Clin Invest 2003;111:649658. [PubMed: 12618519]

McCarthy AL, Woolfson RG, Raju SK, Poston L. Abnormal endothelial cell function of resistance arteries from women with preeclampsia. Am J Obstet Gynecol 1993;168:1323-1330. [PubMed: 7682754] 
McKeeman GC, Ardill JE, Caldwell CM, Hunter AJ, McClure N. Soluble vascular endothelial growth factor receptor-1 (sFlt-1) is increased throughout gestation in patients who have preeclampsia develop. Am J Obstet Gynecol 2004;191:1240-1246. [PubMed: 15507947]

Mills JL, DerSimonian R, Raymond E, Morrow JD, Roberts LJ 2nd, Clemens JD, Hauth JC, Catalano P, Sibai B, Curet LB, Levine RJ. Prostacyclin and thromboxane changes predating clinical onset of preeclampsia: a multicenter prospective study. Jama 1999;282:356-362. [PubMed: 10432033]

Nagamatsu T, Fujii T, Kusumi M, Zou L, Yamashita T, Osuga Y, Momoeda M, Kozuma S, Taketani Y. Cytotrophoblasts up-regulate soluble fms-like tyrosine kinase-1 expression under reduced oxygen: an implication for the placental vascular development and the pathophysiology of preeclampsia. Endocrinology 2004;145:4838-4845. [PubMed: 15284201]

Nevo O, Soleymanlou N, Wu Y, Xu J, Kingdom J, Many A, Zamudio S, Caniggia I. Increased expression of sFlt-1 in in vivo and in vitro models of human placental hypoxia is mediated by HIF-1. Am J Physiol Regul Integr Comp Physiol 2006;291:R1085-1093. [PubMed: 16627691]

Page NM, Woods RJ, Gardiner SM, Lomthaisong K, Gladwell RT, Butlin DJ, Manyonda IT, Lowry PJ. Excessive placental secretion of neurokinin B during the third trimester causes pre-eclampsia. Nature 2000;405:797-800. [PubMed: 10866201]

Paltiel O, Friedlander Y, Tiram E, Barchana M, Xue X, Harlap S. Cancer after pre-eclampsia: follow up of the Jerusalem perinatal study cohort. Bmj 2004;328:919. [PubMed: 15003975]

Rajakumar A, Doty K, Daftary A, Harger G, Conrad KP. Impaired oxygen-dependent reduction of HIF-1alpha and -2alpha proteins in pre-eclamptic placentae. Placenta 2003;24:199-208. [PubMed: 12566247]

Rajakumar A, Whitelock KA, Weissfeld LA, Daftary AR, Markovic N, Conrad KP. Selective overexpression of the hypoxia-inducible transcription factor, HIF-2alpha, in placentas from women with preeclampsia. Biol Reprod 2001;64:499-506. [PubMed: 11159352]

Ray JG, Vermeulen MJ, Schull MJ, Redelmeier DA. Cardiovascular health after maternal placental syndromes (CHAMPS): population-based retrospective cohort study. Lancet 2005;366:1797-1803. [PubMed: 16298217]

Roberts JM. Endothelial dysfunction in preeclampsia. Semin Reprod Endocrinol 1998;16:5-15. [PubMed: 9654603]

Roberts JM, Cooper DW. Pathogenesis and genetics of pre-eclampsia. Lancet 2001;357:53-56. [PubMed: 11197372]

Roberts JM, Taylor RN, Musci TJ, Rodgers GM, Hubel CA, McLaughlin MK. Preeclampsia: an endothelial cell disorder. Am J Obstet Gynecol 1989;161:1200-1204. [PubMed: 2589440]

Said J, Dekker G. Pre-eclampsia and thrombophilia. Best Pract Res Clin Obstet Gynaecol 2003;17:441458. [PubMed: 12787537]

Savvidou MD, Hingorani AD, Tsikas D, Frolich JC, Vallance P, Nicolaides KH. Endothelial dysfunction and raised plasma concentrations of asymmetric dimethylarginine in pregnant women who subsequently develop pre-eclampsia. Lancet 2003;361:1511-1517. [PubMed: 12737861]

Schobel HP, Fischer T, Heuszer K, Geiger H, Schmieder RE. Preeclampsia -- a state of sympathetic overactivity. N Engl J Med 1996;335:1480-1485. [PubMed: 8890098]

Shibata E, Rajakumar A, Powers RW, Larkin RW, Gilmour C, Bodnar LM, Crombleholme WR, Ness $\mathrm{RB}$, Roberts JM, Hubel CA. Soluble fms-like tyrosine kinase 1 is increased in preeclampsia but not in normotensive pregnancies with small-for-gestational-age neonates: relationship to circulating placental growth factor. J Clin Endocrinol Metab 2005;90:4895-4903. [PubMed: 15886253]

Shweiki D, Itin A, Soffer D, Keshet E. Vascular endothelial growth factor induced by hypoxia may mediate hypoxia-initiated angiogenesis. Nature 1992;359:843-845. [PubMed: 1279431]

Sibai BM, Caritis S, Hauth J. What we have learned about preeclampsia. Semin Perinatol 2003;27:239246. [PubMed: 12889591]

Sugimoto H, Hamano Y, Charytan D, Cosgrove D, Kieran M, Sudhakar A, Kalluri R. Neutralization of Circulating Vascular Endothelial Growth Factor (VEGF) by Anti-VEGF Antibodies and Soluble VEGF Receptor 1 (sFlt-1) Induces Proteinuria. J Biol Chem 2003;278:12605-12608. [PubMed: 12538598] 
Taylor RN, Crombleholme WR, Friedman SA, Jones LA, Casal DC, Roberts JM. High plasma cellular fibronectin levels correlate with biochemical and clinical features of preeclampsia but cannot be attributed to hypertension alone. Am J Obstet Gynecol 1991;165:895-901. [PubMed: 1951550]

Thadhani R, Ecker JL, Mutter WP, Wolf M, Smirnakis KV, Sukhatme VP, Levine RJ, Karumanchi SA. Insulin resistance and alterations in angiogenesis: additive insults that may lead to preeclampsia. Hypertension 2004;43:988-992. [PubMed: 15023932]

Thadhani R, Stampfer MJ, Hunter DJ, Manson JE, Solomon CG, Curhan GC. High body mass index and hypercholesterolemia: risk of hypertensive disorders of pregnancy. Obstet Gynecol 1999;94:543550. [PubMed: 10511356]

Toporsian M, Gros R, Kabir MG, Vera S, Govindaraju K, Eidelman DH, Husain M, Letarte M. A role for endoglin in coupling eNOS activity and regulating vascular tone revealed in hereditary hemorrhagic telangiectasia. Circ Res 2005;96:684-692. [PubMed: 15718503]

Vatten LJ, Romundstad PR, Trichopoulos D, Skjaerven R. Pre-eclampsia in pregnancy and subsequent risk for breast cancer. Br J Cancer 2002;87:971-973. [PubMed: 12434286]

Venkatesha S, Toporsian M, Lam C, Hanai J, Mammoto T, Kim YM, Bdolah Y, Lim KH, Yuan HT, Libermann TA, et al. Soluble endoglin contributes to the pathogenesis of preeclampsia. Nat Med 2006;12:642-649. [PubMed: 16751767]

Walker JJ. Pre-eclampsia. Lancet 2000;356:1260-1265. [PubMed: 11072961]

Wallukat G, Homuth V, Fischer T, Lindschau C, Horstkamp B, Jupner A, Baur E, Nissen E, Vetter K, Neichel D, et al. Patients with preeclampsia develop agonistic autoantibodies against the angiotensin AT1. receptor. J Clin Invest 1999;103:945-952. [PubMed: 10194466]

Widmer M, Villar J, Benigni A, Conde-Agudelo A, Karumanchi SA, Lindheimer M. Mapping the theories of preeclampsia and the role of angiogenic factors: a systematic review. Obstet Gynecol 2007;109:168-180. [PubMed: 17197602]

Williams DJ, Vallance PJ, Neild GH, Spencer JA, Imms FJ. Nitric oxide-mediated vasodilation in human pregnancy. Am J Physiol 1997;272:H748-752. [PubMed: 9124434]

Wolf M, Kettyle E, Sandler L, Ecker JL, Roberts J, Thadhani R. Obesity and preeclampsia: the potential role of inflammation. Obstet Gynecol 2001;98:757-762. [PubMed: 11704165]

Wolf M, Sandler L, Munoz K, Hsu K, Ecker JL, Thadhani R. First trimester insulin resistance and subsequent preeclampsia: a prospective study. J Clin Endocrinol Metab 2002;87:1563-1568. [PubMed: 11932283]

Yang JC, Haworth L, Sherry RM, Hwu P, Schwartzentruber DJ, Topalian SL, Steinberg SM, Chen HX, Rosenberg SA. A randomized trial of bevacizumab, an anti-vascular endothelial growth factor antibody, for metastatic renal cancer. N Engl J Med 2003;349:427-434. [PubMed: 12890841]

Zhang J, Meikle S, Trumble A. Severe maternal morbidity associated with hypertensive disorders in pregnancy in the United States. Hypertens Pregnancy 2003;22:203-212. [PubMed: 12909005]

Zhou Y, Bellingard V, Feng KT, McMaster M, Fisher SJ. Human cytotrophoblasts promote endothelial survival and vascular remodeling through secretion of Ang2, PIGF, and VEGF-C. Dev Biol 2003a; 263:114-125. [PubMed: 14568550]

Zhou Y, Damsky CH, Fisher SJ. Preeclampsia is associated with failure of human cytotrophoblasts to mimic a vascular adhesion phenotype. One cause of defective endovascular invasion in this syndrome. J Clin Invest 1997a;99:2152-2164. [PubMed: 9151787]

Zhou Y, Fisher SJ, Janatpour M, Genbacev O, Dejana E, Wheelock M, Damsky CH. Human cytotrophoblasts adopt a vascular phenotype as they differentiate. A strategy for successful endovascular invasion. J Clin Invest 1997b;99:2139-2151. [PubMed: 9151786]

Zhou Y, Genbacev O, Fisher SJ. The human placenta remodels the uterus by using a combination of molecules that govern vasculogenesis or leukocyte extravasation. Ann N Y Acad Sci 2003b;995:7383. [PubMed: 12814940] 